[Aus dem Königl. Institut für Infektionskrankheiten „Robert Koch“ zu Berlin.]

(Direktor: Geh. Obermed.-Rat Prof. Dr. Iooffler.)

(Aus der serologischen Abteilung. Vorsteher: Prof. Dr. Otto.)

\title{
Die Prophylaxe der Serumkrankheit, im besonderen durch antianaphylaktische Schutzimpfungen. ${ }^{1}$
}

Von

R. Otto und P. A. Hoefer.

Es läBt sich nicht verkennen, daB unter dem EinfluB der Ergebnisse der Anaphylaxieforschung die Anwendung der Heilsera, speziell zu prophylaktischen Zwecken, eine gewiße Einschränkung erfabren hat. Dies ergibt sich am besten daraus, daB in den letaten Jahren ein Rückgang bzw. Stillstand im Verbrauch an Diphtherieheilserum, trotz der noch immer erheblichen Verbreitung der Diphtherie, eingetreten ist (Boehncke).

Schon einmal batte die Serumtherapie aus einem ähnlichen AnlaB eine gleiche Krisis zu überstehen, als nämlich gegen die Nitte der 90 er Jahre die ersten Berichte über die unangenehmen Nebenwirkungen des Diphtherieserums mitgeteilt wurden. Damals legten sich die $\mathrm{Be}-$ unruhigungen bald, nachdem sich gezeigt hatte, duB nicht dem Antitoxin als solchem, sondern dem Pferdeserum als artfremdem EiweiB die meist geringen Krankheitserscheinungen (Hautausschläge, Fieber, Gelenkschwellungen) zuzuschreiben waren. Besonders klärend und beruhigend haben später dann die Verhandlungen des Internationalen Kongresses für Hygiene und Demographie im Jahre 1903 gewirkt (Gaffky).

${ }^{1}$ Die Resultate der vorliegenden Untersuchungen wurden von Prof. Dr. Otto am 12. VI. in der Silzung der mikrobiologischen Gesellschaft vorgetragen.

Zeitschr. f. Hygiene. LXXX 
Für Deutschland erstattete damals Geheimrat Loeffler einen Bericht, bei dem er sich auf die Erfahrungen von nicht weniger als 2350 Ärzten beziehen konnte, welche auf den durch Vermittlung des Kaiserlichen Gesundheitsamtes den Ärzten zugesandten Fragebogen geantwortet hatten. Die genannten Ärzte berichteten dabei über Serumschutzimpfungen bei 31740 Personen, darunter 26807 Kindern unter zwölf Jahren. Die Frage der schädlichen Nebenwirkungen des Diphtherieserums konnte Loeffler auf Grund der Enquete dahin beantworten, daß sich die Unschädlichkeit des Serums, abgesehen von einzelnen Fällen, wo Urtikaria und Gelenkschmerzen beobachtet wurden, klar erwiesen habe. Wie Loeffler hinzufügte, mache dies Ergebnis es für den Arzt geradezu zur Pflicht, bei jedem Falle von Diphtherie die bedrohten Individuen der Umgebung der Schutzimpfung zu unterziehen. Auch die übrigen Berichterstatter (Netter für Frankreich, Pavone für Italien, de Torday für Ungarn, Aaser für Norwegen) konnten über nachteilige Wirkungen des Serums nicht berichten, doch riet Netter, Erwachsene wegen ihrer gröBeren Empfindlichkeit nur im Falle besonderer Gefährdung schutzzuimpfen.

Wie gesagt, haben dann einige Jahre später die Ergebnisse der Anaphylaxieforschung von neuem Beunruhigungen hervorgerufen. Weniger taten dies die mehr klinischen Arbeiten von v. Pirquet und Schick. Aus diesen ging zwar in klarer Weise herror, daB die beim Menschen beobachteten Krankheitserscheinungen bei wiederholter Seruminjektion auf reiner "Anaphylaxie" beruhen, indem sich zeigte, daB der menschliche Organismus auf die wiederholte Einverleibung artfremden Serums mit reränderter, in diesem Falle mit beschleunigter und bestärkter Reaktion antwortet; besonders in dem Intervall von 12 Tagen bis 6 Monaten nach einer Seruminjektion pflegt eine hohe Überempfindlichkeit zu bestehen, die zu einer meist sofort einsetzenden Reaktion bei der Reinjektion führt. Beunruhigung trat aber erst ein, als man auf Grund von Laboratoriumsbeobachtungen am Meerschweinchen erfuhr, daB diese Tiere nach einmaliger Vorbehandlung mit minimalen Dosen Pferdeserum bei der zweiten Injektion schwer erkrankten und zum gröBten Teil eingingen. ${ }^{1}$

Die Gefahren der Serumkrankheit beim Menschen wurden indessen zweifellos überschätzt, indem man die im Laboratorium gewonnenen Resultate auf den Menschen übertrug. Wir wissen heute, daB das Meerschweinchen bezüglich der Serumüberempfindlichkeit eine Sonderstellung einnimmt, und daB die an diesen Tieren gewonnenen Erfahrungen nicht so ohne weiteres auf den Menschen übertragen werden dürfen.

'R. Otto; Das Theobald Smithsche Phänomen; Rosenau u. Anderson, Study of the cause of sudden death following the inj. of horse serum. 
Besonders haben dies Gaffky und Heubner betont, welche vor einiger Zeit ein ausführliches Referat über die Gefahren der Serumkrankheit bei der Schutzimpfung mit Diphtherieserum für die wissenschaftliche Deputation für das Medizinalwesen erstattet haben. Sie haben sich durch Klarstellung dieser Tatsachen ein groBes Verdienst erworben. In ihrem ausführlichen Bericht kamen sie zu dem Urteil, daB im Vergleich zum Nutzen des Diphtherieserums die geringen Gefahren der Serumkrankheit nicht ins Gewicht fallen können.

Geheimrat Gaffky führt aus, daB in der Regel die sogenannte Serumkrankheit sowohl bei Erst- als auch bei Reinjizierten leicht verläuft, insbesondere bei Kindern, Ein schwerer Verlauf werde nur in seltenen Fällen beobachtet; er ist nicht auf Reinjizierte beschränkt, sondern kann sich auch bei erstmalig Injizierten ereignen. Unzweifelhaft der Serumkrankheit zur Last zu legende Todesfälle seien in Deutschland, soweit ihm bekannt, in den letzten Jahren nur zwei vorgekommen.

Geheimrat Heubner faßt seine Erfahrungen an der Charitéklinik dahin zusammen, daB im allgemeinen der menschliche Organismus auch in den ersten Kinderjahren eine viel geringere Neigung zu Überempfindlichkeit hat als das kleine Experimenttier, insbesondere das Meerschweinchen, und dab bei sonst gesund veranlagten Kindern eine Gefahr seitens wiederholter Immunisierung bei sublutaner oder intramuskulärer Applikation überhaupt nicht besteht. Bei elenden und an konsumierenden Krankheiten daniederliegenden Kindern dagegen ist bei Reinjektionen nur mit gröBter Vorsicht zu verfahren, und der intravenöse Weg überhaupt ganz zu vermeiden.

Diesen Ansichten kann man auch auf Grund der experimentellen Ergebnisse ohne weiteres zustimmen. Besonders hervorheben möchten wir dabei die überraschènde Tatsache, dab die Todesfälle nach Seruminjektionen, die in der Literatur verzeichnet sind, meistenteils Personen betreffen, die vorber nie eine Seruminjektion erhalten hatten. Andererseits sprechen die Protokolle von v. Pirquet und Schick deutlich dafür, daß die Reinjektion durchaus nicht besonders gefährlich ist. Sie sahen bei reinjizierten Kindern wohl schwere Reaktionen, aber niemals Todesfälle, selbst nicht nach groBen Serumdosen.

Diese Tatsachen legten uns zunächst die Frage nahe, wie das Zustandekommen der Serumüberempfindlichkeit bei den Personen za erklären ist, die früher nachweislich nie mit Serum behandelt worden sind.

AusschlieBen kann man wohl die Annahme, daB dem Heilserum als solchem eine primär toxische Wirkung ${ }^{1}$ zuzuschreiben ist, wie wir sie

1 Soweit uns bekannt, hält nur Friedberger trotz negativer Versuchsergeb. nisse es für möglich, daB auch die antitoxischen Heilsera eine solche primäre Giftig. keit besitzen können. 
im Tierversuch bei manchen hämolytischen und antibakteriellen Seris beobachten können. Hiergegen spricht schon die Tatsache, daß dieselbe Serumnummer, welche von der großen Mehrzahl der Injizierten ohne jede Störung vertragen wird, nur bei ganz vereinzelten Personen ernstere Störungen macht. Damit steht nicht die Erfahrung im Widerspruch, daB die Sera mancher Pferde häufiger Hzantheme verursachen.

Es bleibt also nur anzunehmen, $d a b$ die betreffenden Personen selbst "serumüberempfindlich" gewesen sind.

Diese „Disposition" kann nun, um einer neueren Einteilung ron v. Behring ${ }^{1}$ zu folgen, entweder , angeboren" oder ,erworben" sein. Es gibt zweifellos wohl viele Menschen mit angeborenen Uberempfindlichkeiten. Dabei kann es sich im Sinne v. Behrings um eine "Idiosyn-

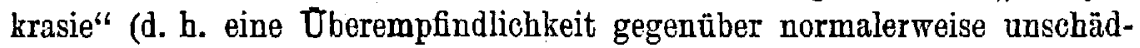
lichen Agenzien ron ganz bestimmter Art) oder um eine "Diathese" (d. h. um eine Überempfindlichkeit gegenüber normalerweise unschädlichen Agenzien der verschiedensten Art). handeln. GröBere Bedeutung als diese ,idiopathischen" Dispositionen dürften aber die "toxopathischen" beanspruchen, also in unserem Falle die (spezifischen?) Anaphylaxien gegenüber dem Pferdeserum, welche „isopathisch" erworben wurden.

Früher wurde, besonders von amerikanischen Autoren, der GenuB von Pferdefleisch, das in manchen Ländern viel genossen werde, als Ursache dieser tberempfindlichkeit gegen das Pferdeserum angeschuldigt. Es würde dazu allerdings wohl erforderlich sein, daB das Fleisch (oder die Milch) von Pferden in groBen Mengen genossen wird, oder aber von Indiriduen, die mit Magen- und Darmstörungen behaftet sind, so daB das artfremde EiweiB ungenügend rerarbeitet, parenteral zu

1 Verschiedene Dispositionsarten nach v. Behring:

A. Idiopathische Disposition (angeboren, konstitutionell, histopathisch oder organopathisch).

I. Idiosynkrasien (= angeborene Überempfindlichkeit gegenüber normalerweise unschädlichen Agenzien von ganz bestimmter Art).

II. Diathesen (= angeborene Überempfindlichkeit gegenüber normalerweise unschädlichen Agenzien der versehiedensten Art).

B. Toxopathische Disposition (isopathisch erworben).

I. Anaphylaxien (= isopathisch erworbene humorigene Überempfindlichkeit gegenüber mehr oder weniger unschüdlichen Agenzien von ganz bestimmter Art, welche von dem anaphylaktischen Individuum mit dem im Blute gelösten anaphylaktischen Antikörper auf normale Individuen übertragen werden kann).

II. Nicht-anaphylaktische Toxin. Überempfindlichkeit (= iso. pathisch erworbene histogene bzw. cytogene, nicht übertragbare Giftüberempfindlichkeit). 
Resorption gelangt. Auf das Zustandekommen solcher ,alimentären" Serumüberempfindlichkeit haben zuerst Rosenau und Anderson auf Grund von Experimenten an Tieren hingewiesen. DaB tatsāchlich beim Menschen die Entstehung der Überempfindlichkeit auf ähnliche Weise möglich ist, lassen die Berichte Rosenthals denkbar erscheinen (zit. nach Doerr), nach denen bei den mit Pferdemilch aufgezogenen Tartarenkindern die "Serumkrankheit" sehr häufig vorkommt. Nun spricht aber unseres Erachtens gegen das Bestehen einer rein spezifischen "Pferdeserum"Anaphylaxie die Tatsache, daB auch nach der Injektion von Schaf- und Rinderserum Exantheme und Serumkrankheit beobachtet werden. Man müBte also annehmen, daß von den Menschen häufig die verschiedensten Formen der Serumüberempfindlichleit erworben werden. Demgegenüber erscheint es uns viel wahrscheinlicher, daB es sich bei diesen überempindlichen Menschen teils wohl um Leute mit sog. „Diathesen" handelt, d. h. um Persunen, die gegen normalerweise unschädliche Agenzien der verschiedensten Art empfindlich sind, hauptsächlich aber um "serumüberempfindliche" Menschen, bei denen die Anaphylaxie aber nicht spezifisch durch $P$ ferde eiweiB erworben ist.

Nach den Untersuchungen von Heilner, Uhlenhuth und Händel, Hailer, Steffenhagen und Clough, Billard und Barbes, Zuntz, Wels und Osborne, Bürger u. a. - auf die hier nur kurz hingewiesen werden soll - ist es nämlich durchaus nicht notwendig, daB die Anaphylaxieerscheinungen stets nur auf eine streng spezifische Sensibilisierung zurüchgeführt werden müssen.

Heilner beobachtete akuten Tod bei Tieren, die mit großen Nengen artfremden Serums vorbehandelt waren, wenn er statt der wiederholten Seruminjektion eine bypertone 4-prozentige Kochsalzlösung injizierte. Uhlenhuth und Händel, sowie Mießner stellten fest, daß gelegentlich ein Übergreifen der Anaphylaxiereaktion auf artfremdes Eiweiß stattfindet, wemn die betreffenden Substanzen (Nahrungsmittel) gekocht waren. Hailer fand, da $B$ die Hitzedenaturation die spezifisch sensibilisierenden Eigenschaften der Proteine beeinträchtigt. Steffenhagen und Clough beobachteten bei Untersuchungen über die Herkunft von Knochen gleichfalls ein starkes Übergreifen der Reaktion auf artfremdes Eiweib, wenn das Ausgangsmaterial eine halbe Stunde lang strömendem Wasserdampf ausgesetzt war. Billard und Barbes konnten bei Kaninchen, die gegen Pferdeserum überempfindlich gemacht waren, noch nach Monaten anaphylaktische Reaktionen durch Nethylenblauinjektionen erzielen. Zuntz sah unspezifische Anaphylaxie gegenüber Ochsenserum nach Vorbehandlung mit primären Albumosen. Wels und Osborne gelang die Anaphylaktisierung mit Getreideeiweißkörpern, wobei gleichfalls die Spezifizität oftmals verwischt war. Bürger konnte bestätigen, daB höhere Temperaturen den Arteharakter der Anaphylaktogene aufheben können. So sah er besonders ein Übergreifen der Reaktion nach der Vorbehandlung mit Fleischextrakten. Tiere, die mit Rind- 
fleischextralkt vorbehandelt waren, erwiesen sich überempfindlich auch gegen Schweine- und Hammelserum. Mit Hammelfeischextrakt vorbehandelte Tiere waren überempfindlich gegen Schweine-, Rinder- und Kaninchenserum. Besonders bei der Verwendung von gekochten Extrakten ging die Spezifizität leicht verloren.

Es ist hiernach sehr wohl möglich, daB eine Serumüberempfindlichkeitgegenüber dem Pferdeserum durch die parenterale Resorption irgend eines anderen körperfremden ${ }^{1}$ EirveiBes entstanden sein hann. Daraus folgt, daB man bei solchen überempfindlichen Personen weder mit dem PferdeeiweiB allein als sensibilisierender Substanz, noch mit einer spezifischen Anaphylaxie gegenüber Pferdeserum allein rechnen muB. So erklärt es sich auch, daB allerlei körperfremde Substanzen Ursache einer "Uberempfindlichkeit" sein können und die Veranlassung zu „Exanthemen" geben, und daB auBer den Pferdeserum-Injektionen auch die Applikation anderer Sera (z. B. Rinderund Schafserum) unangenehme Zufälle bei solchen Individuen hervorrufen. Aus diesem Grunde ist auch unseres Erachtens mit der Vermeidung des Pferdeserums and der Anwendung anderer Tiersera die Gefahr einer Serumkrankheit durchaus nicht sicher ausgeschlossen. ${ }^{2}$ Der alleinige Vorzug der Verwendung dieser letzteren Sera wäre der, daB nur die Gefahr der Erzeugung einer spezifischen Pferdeserum-Anaphylaxie umgangen wird. Wie aber bereits gesagt, ist die Serumkrankheit der Reinjizierten nicht die einzige Gefahr, welche bei der Serumanwendung droht, sondern viel häufiger sind solche Personen betroffen, welche vorher niemals mit Pferdeserum vorbehándelt wurden. Diese letzteren Zufälle sind deshalb um so unangenehmer, weil das Bestehen einer solchen Anaphylaxie meist unbekannt ist, während sich eine schon früher einmal voraufgegangene Serumbehandlung durch die Anamnese leicht ermitteln lieBe.

Wir haben uns nun die weitere Frage vorgelegt, ob sich nicht auch die Gefahr der Serumkrankheit bei diesen höchstwahr. scheinlich an einer unspezifischen Überempfindlichkeit leidenden Personen vermeiden läBt? Diese ist nach dem Gesagten durch Vermeidung des Pferdeserums allein nicht beseitigt.

${ }^{1}$ Da nach Wolf-Eisner auch körpereigenes Eiweik zu Überempfindlichkeitserkrankungen führen soll, z. B. bei Basedow scher Krankheit, so müBte man auch bei diesen Kranken mit (eventuell aspezifischen) Reaktionen rechnen. Solche Reaktionen sind nach Wolf-Eisner im übrigen bei allen Menschen mit labilem Vasomotorenapparat zn erwarten.

${ }^{2}$ Derartige Vorschläge haben Ascoli, Jochmann u. a. gemacht. Statt des Pferdeserums soll antitoxisches Hammel- bzw. Rinderserum verwandt werden. Demgegenüber möchten wir noch daranf hinweisen, daB das Pferdeserum vom Menschen mit am besten von allen Serumsorten vertragen wird (siehe auch Doerr, a. a. o.) 
Zunächst wird es sich darum handeln, ob sich das Bestehen einer "Oberempfindlichkeit" erkennen läBt. Nach den vorliegenden Erfahrungen sind Personen mit asthmatischen Beschwerden, die besonders beim Betreten von Pferdeställen auftreten, sowie Menschen mit sonstigen "Diathesen" als verdächtig anzusehen. Häufig bestehen aber absolut keine Anzeichen, die auf das Vorliegen einer Anaphylaxie hinweisen. Hier könnten vielleicht serologische oder ähnliche Realtionen AufsehluB bringen.

Zur serologischen Diagnose auf "Anaphylaxie" käme einmal die Untersuchung des Blutes auf seinen Gehalt an "anaphylaktischen Reaktionskörpern", die R. Otto im Jahre 1908 bereits empfohlen hat, in Frage. Bruck u. a. ist auf diese Weise der Nachweis von Antikörpern, z. B. bei einer gegen Schweinefleisch bestehenden Idiosynkrasie gelungen, ebenso bei einer Überempfindlichkeit gegen Hühnereiweiß (zit. nach Doerr). Da zur Feststellung der Antikörper indessen der Tierversuch erforderlich ist, so würde diese Methode bei Fällen von akuten Infektionskrankheiten, wo die Serumtherapie ungesäumt eingeleitet werden muß, zu spät kommen. Auch die Anstellung der Präzipitinreaktion wird keine besseren Aussichten bieten, da nach den vorliegenden Erfahrungen derartige Personen keine Präzipitine im Blute zu enthalten pflegen. Wenig empfehlenswert scheint uns auch die Bauersche Reaktion (Vorhandensein von Agglutininen auf Pferdeblutkörperchen) zu sein, da sie nur im Laboratorium anzustellen ist. Auch ist sie bisher wenig erprobt ist. Viel einfacher wäre ein anderer Weg, nämlich die Anwendung einer probatorischen „kutanen" bzw. "subkutanen" Reaktion. Wie wir nach den Untersuchungen von v. Pirquet und Schick wissen, reagieren hochüberempfindliche Personen auf die subkutane Injektion des Serums zum Teil mit sofortigen lokalen Erscheinungen, und diese Autoren haben die diagnostische Bedeutung dieser Reaktionsfähigkeit auch erkannt. Man könnte also zunächst kleine Serummengen, die sicher unschädlich sind, sublkutan oder intrakutan ${ }^{1}$ injizieren und die Reaktion abwarten. Nach neueren Untersuchungen an Tieren, über die Dr. Blumenthal an anderer Stelle berichten wird, scheint übrigens die intrakutane Injektion nur bei hochüberempindlichen Meerschweinchen zur Diagnose auf das Vorliegen von Überempfindlichkeit brauchbar zu sein und erst nach 18 Stunden einzutreten. Eingehendere Erfahrungen über die Kutanreaktionen liegen bisher jedenfalls nicht vor. Ist daher eine schnelle und sichere Diagnose auf das Vorliegen von Serumüberempfindlichkeit nicht möglich, so muB die Prophylaxe der Serumkrankheit so aufgebaut werden, daB sio in allen Fällen mit der Möglichkeit einer solchen rechnet. Wir möchten aber gleich an dieser Stelle betonen, daB natürlich in allen Fällen, wo der Krankheitszustand die sofortige Anwendung von Serum erforderlich macht, es für den Arzt ausgeschlossen sein muB, allein aus Rücksicht auf die Serumkrankheit mit der Anwendung des Heilserums zu warten.

1 Die intrakutane Injektion zur Diagnose der Seramüberempfindlichkeit hat als erster Moss beim Menschen angewandt. Von 21 früher (4 Monate bis $10 \mathrm{Jahre}$ ) mit Serum injizierten Personen reagierten innerhalb 6 bis 24 Stunden: $11-, 7+, 3++$ 
Am idealsten wäre es nun natūrlich, wenn es gelänge, dem Serum durch irgendwelche Manipulationen seine Giftigkeit für überempindliche Personen zu nehmen. Von diesem Ziele sind wir, wie weiter unten gezeigt: werden soll, noch weit entfernt. Ebensowenig besitzen wir bisher pharmakologische Mittel ${ }^{1}$, welche sich bei der Serumkrankheit als sicher helfend und schützend bewährt haben. Dagegen wissen wir aus der Anaphylaxieforschung, dab es im Tierversuch mit Leichtigkeit gelingt, durch die Applikation kleiner, mehr oder weniger ungefährlicher Serumdosen einen Schutz gegenüber der nachfolgenden Seruminjektion zu erzielen.

Schon R. Ot to hatte bei seinen ersten Versuchen gezeigt, daB es möglich ist, die Überempfindlichkeit von Meerschweinchen durch geeignete Zufuhr ron Antigen für längere Zeit aufzuheben. Die gleiche Erscheinung ist ron Rosenau u. Anderson beobachtet und später besonders ron Besredka studiert und mit dem Namen der "Antianaphylaxie" belegt worden.

Neufeld hat wohl als erster auf Grund von Versuchen mit Wedemann vorgeschlagen, auch beim Menschen diese Antianaphylaxie zur Vermeidung von unangenehmen Zufällen bei der Injektion von Heilserum anzuwenden, und zwar gelegentlich seiner Untersuchungen über die Serumtherapie der Pneumonie, bei der intravenöse Injektionen größerer Serummengen von ihm empfohlen wurden. Ähnliche Vorschläge stammen von Besredka, Doerr, Friedberger u. a. Tatsächlich liegen nun auch schon beim Menschen einige Erfahrungen über die prophylaktische Serum. injektion zwecks Erzielung der Antianaphylaxie ror. Am vollkommensten wäre die Methode natürlich dann, wenn es gelänge, durch die Injektion vōllig ungefährlicher kleiner Serumdosen absoluten Schutz gegenüber den nachfolgenden größeren Serumdosen, bzw. durch voraufgehende subkutane gegen die nachfolgende intravenöse und intraspinale Seruminjektion zu erzielen.

Uber die nach dieser Richtung bisher vorliegenden Erfahrungen schreibt Doerr:

Nach Lissowskaja, Rosanow wäre diese prophylaktische Injektion mit $0.05^{\mathrm{cm}}$ pro Kilogramm Körpergewicht $\mathrm{zu}$ bemessen, und dürfte die eigentliche Heildosis nicht früher als nach zwei Stunden nachinjiziert werden. Die prophylaktische Dosis soll nach Rosanow, Gaussel u. a. keine Erscheinungen erzeugen und die Folgen der Heildosis völlig verhindern oder doch bedeutend absehwächen, was aber mit den Erfahrungen von Netter, Grysez und Dupuich im Widerspruch steht, durch welche insbesondere die Un-

1 Atropin, Chloralhydrat, Chlorbarium usw. sind von verschiedenen Seiten empfohlen worden. Als ein sicher wirkendes Mittel hat sich keins bewährt. 
gefährlichkeit der prophylaktischen Injektion wenigstens für bestimmte Fälle in Frage gestellt wird. Noch bedenklicher müBte es sein, die prophylaktische Injektion in dem von Rosanow verlangten Ausmal $(0.4$ bis $2 \cdot 0^{\mathrm{ccm}}$ ) intravenös vorzunehmen und die Heildosis 10 Minuten später nach. folgen zu lassen; wenn auch Rosanow an seinem Material keine bedenklichen Zufälle sah, so könnten sie doch bei gewissen Individuen, wie die Fälle von Netter, Grysez und Dupuich zeigen, eintreten. Das Verlangen von Netter erscheint daher berechtigt, die prophylaktische Seruminjektion vorsichtiger zu dosieren, besonders wenn sie direkt in die Venen ausgeführt wird. In letzterem Falle wäre es übrigens gar nicht nötig, die prophylaktische von der Heildosis durch ein längeres Intervall zu trennen, vielmehr könnte man die gesamte Serummenge zwar intravenös, aber fraktioniert und zunächst in sehr kleinen Dosen injizieren (Doerr, Friedberger). Da die Anaphylaxie sehr rasch eintritt, können die einzelnen Portionen ziemlich schnell aufeinander folgen, und es müBte daher auch möglich sein, das Fraktionieren durch ein langsameres Tempo der Injektion zu ersetzen (Doerr). Friedberger und Mita haben in der Tat experimentell gezeigt, daB aktir sensibilisierte Meerschweinchen 10 fache Multipla der letalen Antigendosis vertragen, wenn man dieselbe nicht innerhalb weniger Sekunden, sondern innerhalb von 50 bis 60 Minuten intravenös einspritzt; die Autoren betonen, daB die günstige Wirkung der verlangsamten Injektionsgeschwindigkeit auch dadurch unterstützt wird, daß bekanntermaßen zur Neutralisation einer ge. gebenen Menge Antikörper weniger Antigen bei fraktioniertem Zusatz ausreicht. Sie konstruierten einen Apparat für intravenöse Seruminjektionen beim Menschen, der eben auf das Prinzip aufgebaut ist, daB das Serum zwar fortlaufend, aber immer nur in Spuren in die Zirkulation gelangt. Praktische Erfahrungen stehen noch aus. ${ }^{1}$

Aus dem Referat Doerrs ist ersichtlich, daB die Frage nach der Dosis der beim IIenschen anzuwendenden Schutzimpfung noch nicht gelöst ist. Es ist zweifellos richtig, daB die intrarenöse Serumiujektion ron 0.4 bis 2.0 $0^{\mathrm{ecm}}$ Serum höchst bedenklich erscheinen muB. Traten doch in dem ron R. Otto in der ron Leuthold-Gedenkschrift zitierten Falle (Kind Rauschenbusch) schon nach der subkutanen Injektion ron $0.8^{\mathrm{cm}}$ Heilserum schwere Serumerscheinungen auf. Auch bei den in der Literatur erwähnten Todesfällen nach Seruminjektionen betrug die (subkutan applizierte) Serummenge häufig nur wenige (2 bis 5) Kubikzentimeter. In dem bekannten Falle Langerhans war sogar nur $1.2^{\text {cen }}$ subkutan verabreicht worden. Einzelne Autoren (z. B. Kolle u. Hetsch) schlagen deshalb vor, mit ganz geringen Dosen zur Erzielung der Antianaphylazie

1 Auch die von Friedberger u. Mita auf Grund von Tierversuchen empfohlene Anwezdung von Kälte (Abkühlung des Körpers auf $30^{\circ} \mathrm{C}$ ) dürfte für die praktische Verwendung beim Menschen kaum in Frage kommen. - In der Praxis hat sich übrigens bei Collapsen nach Seruminjektionen gerade die Applikation von Wärme verbunden mit Alkohol- und Strychuingaben bewährt, wie u. a. A. Bankier Sloan berichtet. 
zu beginnen $(0.1$ bis $0.2 \mathrm{ccm})$. Mongour sah aber selbst nach der subct. Vorinjektion von 0.25 bis $1.0^{\mathrm{ecm}}$ bei der späteren Reinjektion gröBerer Serumdosen noch deutliche, wenn auch weniger intensive und kürzere Reaktionen als sonst.

Andererseits hat sich in der Veterinärpraxis und bei Immunisierungsversuchen im Laboratorium (so z. B. nach mündlicher Mitteilung von Geh.-Rat..Loeffler auch bei der Herstellung des Serums gegen Haulund Klauenseuche) die Methode der Antianaphylaxie-Erzeugung durch vorher injizierte kleine Antigendosen durchaus bewährt.

Von diesen Tatsachen ausgehend, haben wir nochmals experimentell die Frage geprüft, von welchen möglichst kleinen Serumdosen und nach welcher Zeit im Tierversuch überhaupt ein antianaphylaktischer Schutz zu erwarten ist. Als Versuchstiere wählten wir Meerschweinchen, bei denen sich bekanntlich die höchsten Grade der Serumüberempfindlichkeit mit größter Leichtigkeit und RegelmäBigkeit erzielen lassen. Die Vorbehandlung geschah subkutan mit wechselnden Serumdosen.

Zur Erzeugung der Antianaphylaxie haben wir aus praktischen Gründen in der Regel die einmalige subkutane Seruminjektion verwandt, da nur diese für den Arzt in der Praxis in Betracht kommen dürfte. Sie ist einfach auszuführen, wenig zeitraubend und am ungefährlichsten. Daneben könnte beim Menschen die intramuskuläre oder die intravenöse Injektion in Frage kommen. Der ersteren gegenüber hat die subkutane Serumanwendung den Vorteil, da 3 sich bei ihr eine etwa bestehende hochgradige Serumüberempfindlichkeit bereits durch eine lokale Hautreaktion erkenntlich machen kann. Die intravenöse Injektion ist, wie anch unsere späteren Versuchsergebnisse zeigen werden, zu gefährlich bei schneller Injektion sicher schützender Dosen, oder aber za zeitraubend bei der ungefährlichen, sehr protrahierten Injektion. Denn um die schützenden Dosen gefahrlos zu injizieren, z. B. mit dem Friedberger Mitaschen Apparat, wäre eine Zeit von 50 bis 60 Minuten erforderlich, die dem praktischen Arzt für jeden mit Serum zu behandelnden Fall nicht zur Verfügung stehen dürfte.

Zur Erzielung der Antianaphylaxie bedienten wir uns bei der Reinjektion auschlieBlich des (inaktivierten) Pferdeserums, wie es als Träger des Diphtherieantitoxins in den Handel kommt.

Zwar hatte R. Otto bei früheren (bisher nicht publizierten) Versuchen beobachtet, daß man auch bei hochüberempfindlichen Meerschweinchen durch heterologe Sera ${ }^{1}$ einen gewissen Schutz erzielen kann, doch war dieser nur

${ }^{1}$ Die Versuche waren mit Ziegenserum an Meerschweinchen, die gegen Pferdeserum überempfindlich gemacht waren, angestellt. 
nach der subkutanen und intraperitonealen Injektion groBer Dosen $\left(5^{\mathrm{ccm}}\right)$ vorhanden; kleinere Dosen $\left(2.5^{\mathrm{ccm}}\right)$ gaben schon unsichere Erfolge oder wirkten sogar schädigend. Neuerdings haben Friedberger und Ot to berichtet, daß auch normales Kaninchenserum bei spezifisch anaphylaktisierten Tieren (z.B. gegen Pferdeserum) einen gewissen Schutz gegen die nachfolgende Injektion des homologen Serums gewähren kann. Für die allgemeine Praxis dürfte die Injektion derartiger Sera aber nur in beschränktem MaBe verwendbar sein, da - wie gesagt - die Serumempfindlichkoit der Erstinjizierten nicht spezifisch allein gegen Pferdeserum gerichtẹt zu sein braucht.

Zur Prüfung des durch die erste Reinjektion erzielten Schutzes verwandten wir (mit einigen Ausnahmen, siehe Versuch VI u. VII) intravenōse Serumapplikationen und zwar haben wir regelmäBig die mehrfach tödliche Dosis $(0.5 \mathrm{~cm}$ Serum) gegeben.

Im einzelnen rerliefen die Versuche folgendermaßen:

Eine Anzahl Meerschweinchen wurden jedesmal durch die subkutane Injektion von $(0.01$ bis $10.00 \mathrm{ccm})$ normalem Pferdeserum sensibilisiert. Nach 3 Wochen erwiesen sich die Tiere gegenüber der intravenösen Reinjektion hochüberempfindlich (meist erfolgte nach $0.25 \mathrm{ccm}$ akuter Tod).

$$
\text { Tabelle I. }
$$

Neerschweinchen, 1 mal vorbehandelt mit $0.01 \mathrm{~cm}$ normalem Pferdeserum subkutan.

Reinjektion: intrarenös (fallende Dosen). - Prüfung: intravenōs $\left(0.5^{\mathrm{ccm}}\right.$ ).

\begin{tabular}{|c|c|c|c|c|c|}
\hline \multicolumn{3}{|c|}{ Reinjektion: a) nach 3 Wochen: } & \multicolumn{3}{|c|}{ b) nach 5 wochen: } \\
\hline $\begin{array}{l}\text { Dosis } \\
\text { (in cem) }\end{array}$ & & $\begin{array}{l}\text { Prüfung nach } \\
20 \text { Stunden }\end{array}$ & $\begin{array}{c}\text { Dosis } \\
\text { (in ccm) }\end{array}$ & & $\begin{array}{l}\text { Prüfung nach } \\
20 \text { Stunden }\end{array}$ \\
\hline $1 \cdot 0$ & $\bar{b}$ & . & 1.0 & Mee.11: $+3^{\prime}$ & B \\
\hline $1 \cdot 0$ & ø & - & 1.0 & $\Rightarrow 12: \times x$ & 0 ? \\
\hline 0.5 & Mee. $1:+12$ & $\emptyset$ & 0.5 & $\mathfrak{g}$ & - \\
\hline 0.5 & $, 2:+15$ & $g$ & 0.5 & $g$ & $\cdot$ \\
\hline $0 \cdot 25$ & $" 3:+10^{\prime}$ & $\mathfrak{g}$ & 0.25 & Mee.13: $+5^{\prime}$ & ø \\
\hline $0 \cdot 25$ & $, 4: x \times x$ & 0 ? & 0.25 & $" 14: \times \times \times$ & $x \times x$ \\
\hline $0 \cdot 1$ & " $\check{\mathbf{5}}: \times \times \times$ & $+5^{\prime}$ & & & \\
\hline 0.1 & $" 6: \times \times \times$ & ? & & & \\
\hline 0.05 & $\Rightarrow 7: \times \times$ & $x \times x$ & & - & \\
\hline 0.05 & $" 8: \times x$ & $\times \times \times$ & & & \\
\hline $0 \cdot 01$ & "9: $\times$ & $\times \times \times$ & & & \\
\hline 0.01 & $\eta 10: x$ & $+15^{\circ}$ & & & \\
\hline \multicolumn{6}{|c|}{ Zeichenerklärung: } \\
\hline \multicolumn{6}{|c|}{$\mathfrak{g}=$ Versuch nicht angestellt } \\
\hline \multicolumn{6}{|c|}{$x \times x=$ schwer krank. } \\
\hline \multicolumn{2}{|c|}{$\times \times=$ deutlich } & rank. & \multirow{3}{*}{\multicolumn{2}{|c|}{. }} & \multirow{3}{*}{. } \\
\hline 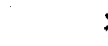 & \multirow{2}{*}{\multicolumn{2}{|c|}{$=$ leicht krank. }} & & & \\
\hline & & & & & \\
\hline
\end{tabular}


In der ersten Versuchsreihe wurden die mit $0.01^{\mathrm{cen}}$ sublutan anaphylaktisierten Tiere mit fallenden Dosen Pferdeserum intravenös reinjiziert $\left(0.5\right.$ bis $\left.0.01^{\mathrm{cm}}\right)$. Während beide Tiere, die mit $0.5^{\mathrm{cm}}$ injiziert waren, und eins von den Tieren mit 0.25 akut starben, kimen die anderen Tiere mit dem Leben davon. Die überlebenden Tiere hatten bei 0.1 und $0.25^{\mathrm{cm}}$ sehr schwere, bei $0.05 \mathrm{~cm}$ deutliche und bei $0.01 \mathrm{~cm}$ leichte Krankheitserscheinungen gezeigt. Nach 20 Stunden hatten sich alle Tiere, auch die schwer kranken, völlig erholt, und es erfolgte nun die erneute Seruminjektion von $0 \cdot 5^{\mathrm{cm}}$ intravenös. Es zeigte sich danach, daB nur zwei Tiere genügend antianaphylaktisiert waren, und zwar je ein Tier, das am Tage vorher $0.25^{\mathrm{cm}}$ bzw. $0.1^{\mathrm{ccm}}$ erhalten hatte und schwer erkrankt gewesen war. Alle übrigen Tiere erkrankten von neuem schwer oder gingen akut ein.

Mit Tieren derselben Serie wurde 5 Wochen nach der Sensibilisierung ein ähnlicher Versuch vorgenommen, und zwar sind diesmal 2 Tiere mit L.0 und 2 Tiere mit $0.25 \mathrm{~cm}$ reinjiziert. Die Dosis von $1.0 \mathrm{~cm}$ war absichtlich gewählt, um zu präfen, ob etwa die nach übertödlichen Dosen mit dem Leben ausnahmsweise davonkommenden Tiere gegen weitere Injektionen geschützt sind. Wie die Prüfung nach 20 Stunden zeigte, war dies tatsächlich bei dem einen davongekommenen Tiere der Fall (Meerschw. 12). Das Tier, Meerschw. 14, welches am Tage vorher nach $0.25^{\mathrm{cm}}$ schwer erkrankt gewesen war, erkrankte trotzdem von neuem schwer. Es zeigt sich also, $\mathrm{daB}$ bei manchen Tieren trotz schwerstem anaphylaktischen Anfall keine sichere Antianaphylaxie zustande kommt, eine Erscheinung, die ja schon früher bekannt war, und die durch das Beispiel der Tiere Meerschw. 5 und Meerschw. 14 klar demonstriert wird.

Des weiteren geht aus diesem Versuche hervor, daß die intravenöse Schutzimpfung zur Erzeugung der Antianaphylaxie wenig ge. eignet ist. Nur sehr hohe, lebensgefährliche Serumdosen bedingen einen deutlichen Schutz, der dabei, trotz des Überstehens schwerster anaphylaktischer Erscheinungen, oft ein unsicherer ist. Wir haben deshalb von weiteren Versuchen, die Antianaphylaxie durch intravenöse Seruminjektionen zu orzielen, bei dieser Tierserie abgesehen.

In der zwoiten Versuchsreihe wurden die Meerschweinchen in gleicher Weise wie im Versuch I durch die Injektion von $0.01^{\mathrm{cm}}$ normalem Pferdeserum sensibilisiert. Die Schutzimpfung erfolgte in diesem Falle aber subkutan und zwar mit fallenden Serumdosen von $8.0 \mathrm{bis} 0 \cdot 1^{\mathrm{ccm}}$. Da die Überempfindlichkeit der Tiere zwar nach 3 Wochen völlig ausgebildet ist, aber später in der Regel noch deutlicher wird, so sind mit den Tieren derselben Serie Versuche nach 3 Wochen, 4 Wochen, 5 Wochen und 7 Wochen angestellt worden. Die Schwere der Reaktion bei der Reinjektion hing natürlich von der Dosis des zur Schutzimpfung verwandten Serums ab. Die mit 0.1 und 0.25 cem behandelten Tiere zeigten keine Erscheinungen, die mit 0.5 und $1.0 \mathrm{~cm}$ behandelten Tiere zweifelhafte oder leichte Symptome, die mit $2 \cdot 0^{\mathrm{cm}}$ und höheren Dosen behandelten Tiere (mit einer Ausnahme) deutliche oder sehr schwere Erscheinungen. Bei der nach 20 Stunden vorgenommenen Prüfung, die wie immer, mit $0.5 \mathrm{ccm}$ intravenös angestellt wurde, erwiesen sich die mit den kleinen Dosen $\left(0.1\right.$ und $\left.0.25^{\mathrm{com}}\right)$ schutzgeimpften Meerschweinchen als schlecht antianaphylaktisch. Dagegen war bei den Tieren nach der Injektion von $0.5^{\mathrm{cm}}$ und höheren Dosen ein deutlicher Schutz unverkennbar. Die Tiere, 


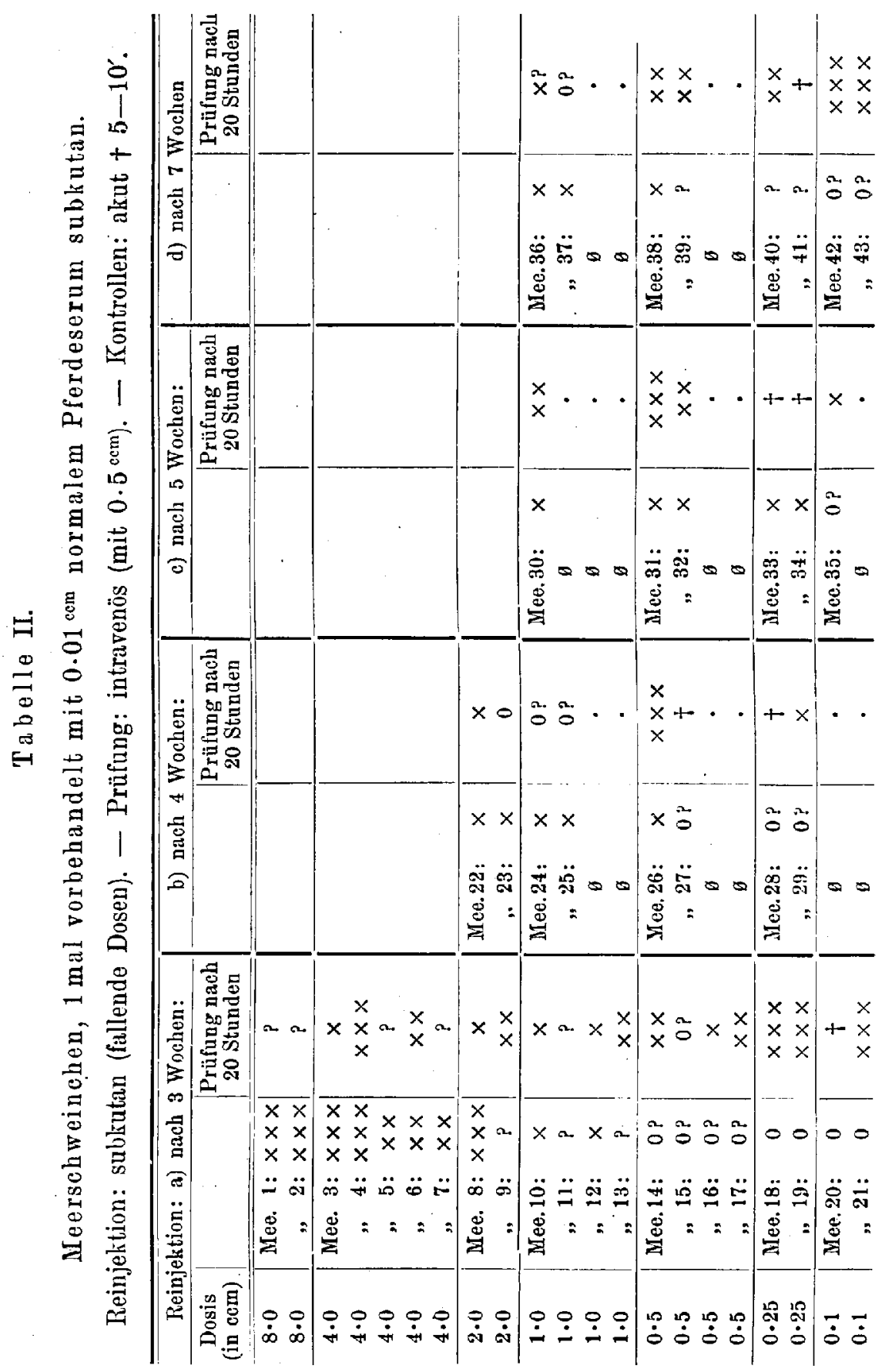


welche die gröBten Dosen erhalten hatten $\left(8 \cdot 0^{\mathrm{ccm}}\right)$, und einige aus der Reihe mit $4 \cdot 0^{\mathrm{ccm}}$ zeigten keine deutlichen Erscheinungen. Bei der Wiederholung der Versuche mit den Tieren derselben Serie nach 4, 5 und 7 Wochen ergab sich im allgemeinen dasselbe Resultat, doch ist bemerkenswert, daß jetzt die Tiere bei der Schutzimpfung mit 0.5 und $1.0 \mathrm{~cm}$, nach 5 Wochen auch die mit der Dosis von 0.25 meist leichte Krankheitserscheinungen zeigten, ein Zeichen, daB bei ihnen die Anaphylaxie dentlicher ausgebildet war, wie nach 3 Wochen. Dem entspricht auch die Tatsache, daß die mit kleinen Dosen $0 \cdot 25$ bis $0 \cdot 5^{\mathrm{cem}}$ vorbehandelten Tiere schlechter geschützt waren, als bei dem Versuch 3 Wochen nach der Sensibilisierung. Hieraus ergibt sich zugleich der wichtige SchluB, daß die Stärke der Reaktion bei der. Prüfung auf Antianaphylaxie ein besserer Wertmesser für die vorhanden gewesene Anaphylaxie ist, als die Reaktion bei der ersten (subkutanen) Reinjektion.

\section{Tabelle III.}

Meerschweinchen, 3 mal vorbehandelt mit $0.01^{\mathrm{com}}$ subutan (in Abstand ron 6 Tagen).

Reinjektion: subkutan. - Prüfung: intravenös $\left(0 \cdot 5^{\mathrm{ccm}}\right)$.

Kontrollen: akut + .

\begin{tabular}{|c|c|c|c|}
\hline \multicolumn{4}{|c|}{ Subkutane Reinjektion nach 3 Wochen (nach der letzten Injektion): } \\
\hline $\begin{array}{c}\text { Dosis } \\
\text { (in ccm) }\end{array}$ & & & Prüfung nach 20 Stdn. \\
\hline $8 \cdot 0$ & Nee. 551: & $x \times x$ & $x$ \\
\hline $8 \cdot 0$ & , $552:$ & $\times \times$ & $x$ \\
\hline $4 \cdot 0$ & Mee. 553: & $t$ & $\emptyset$ \\
\hline 4.0 & , $554:$ & $x ?$ & $x \times x$ \\
\hline $2 \cdot 0$ & Mee. 555: & $x$ & $x$ \\
\hline $2 \cdot 0$ & , 556: & $x \times x$ & $x$ \\
\hline $2 \cdot 0$ & " 557: & $x \times$ & $x$ \\
\hline 2.0 & $\because \quad 558$ : & $x \times x$ & $\times$ \\
\hline 1.0 & Mee. 559: & $x \times$ & $x$ \\
\hline $1 \cdot 0$ & $" 560:$ & $?$ & $x \times x$ \\
\hline 1.0 & " 561: & $x$ & $x \times x$ \\
\hline $1 \cdot 0$ & \# 562: & $?$ & $x \times x$ \\
\hline 0.5 & Mee. ${ }^{\ddagger} 563:$ & $x$ & $x \times x$ \\
\hline 0.5 & " $564:$ & $?$ & $x \times x$ \\
\hline 0.5 & , 565: & ? & $x$ \\
\hline 0.5 & $\# 566:$ & $?$ & $x \times$ \\
\hline 0.25 & Mee. 567: & 0 & $x \times x$ \\
\hline 0.25 & \#568: & $?$ & $t$ \\
\hline 0.1 & Mee. 569 : & 0 & $t$ \\
\hline $0 \cdot 1$ & , 570: & 0 & $x \times$ \\
\hline
\end{tabular}


Die Prophylaxe der Serumerankheit usw.

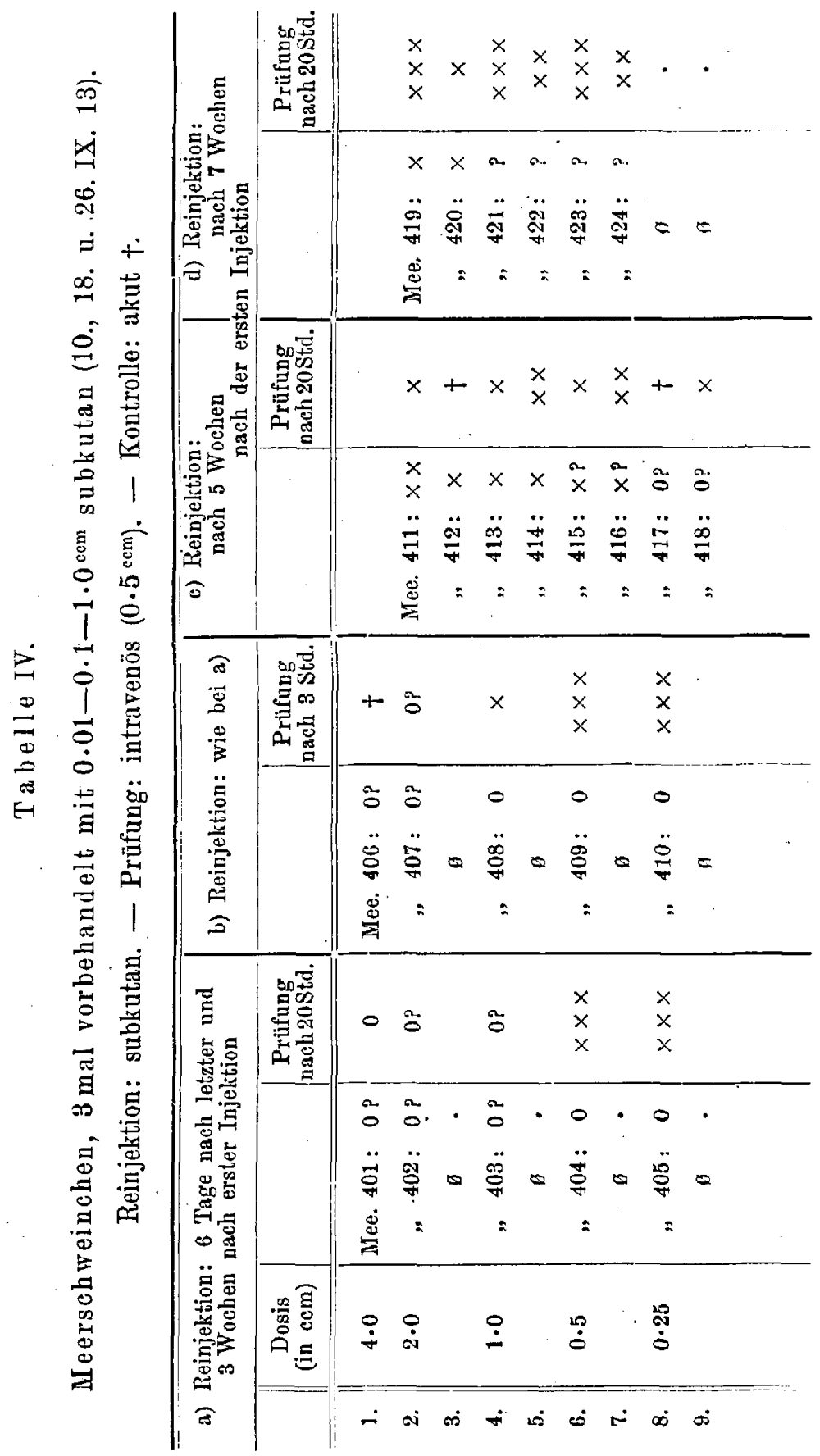


In einer dritten Versuchsreihe wurde die Sensibilisierung statt durch einmalige durch die dreimalige Vorbehandlung mit kleinsten Serummengen $\left(0.01^{\mathrm{ccm}}\right)$ vorgenommen, ein Verfahren, das nach dem Befund von R. otto stärkere Grade ron Anaphylaxie erwarten ließ. Dab solche bei den Tieren, als sie 3 Wochen nach der letzten Injektion erneut in Versuch genommen wurden, tatsächlich vorlag, geht aus den Versuchsergebnissen hervor. Besonders tritt die erhöhte Empfindlichkeit der Tiere wieder bei der Prüfung (20 Stunden nach der Schutzimpfung) zutage. Selbst die mit 1.0 cem geschützten Tiere erkrankten zum groben Teil noch schwer.

In derVersuchsreiheIV ist die Sensibilisierung mit steigenden Dosen $0 \cdot 01-0 \cdot 1-1 \cdot 0^{\mathrm{eem}}$ ausgeführt, ein Verfahren, das im Gegensatz zu Serie III bei der ersten Reinjektion, die subkutan erfolgt, geringere Anaphylaxiegrade erwarten liek, wie dies auch der Verlauf der Versuche bestätigt hat, trotzdem die Kontrollen nach der intravenösen Injektion von $0.5 \mathrm{~cm}$ Serum prompt akut eingingen. Bei diesen Tieren sind die Versuche 3 Wochen, 5 Wochen und 7 Wochen nach der ersten Sensibilisierungsinjektion vorgenommen. Die Prüfung auf den durch die Reinjektion erzielten Schutz erfolgte wie üblich nach 20 Stunden. Bei dem Versuch 3 Wochen nach der ersten (bzw. 6 Tage nach der letzten) Injektion ist zum Vergleich mit der nach 20 Stunden bestehenden Antianaphylaxie auch auf Antianaphylaxie 3 Stunden nach der Schutzimpfung geprüft worden. Die Versuchsergebnisse zeigen, daß ein antianaphylaktischer Schutz schon nach 3 Stunden erkennbar ist, wenngleich derselbe hinter dem nach 20 Stunden vorhandenen zurückbleibt.

Im übrigen zeigte sich bei diesen Tieren, da $\beta$ der erzielte Schutz nach der Injektion von $0.5 \mathrm{~cm}$ unsicher und in der Regel erst nach $1.0 \mathrm{~cm}$ deutlich ist. Doch schwankt der Grad der Antianaphylaxie, wie aus der Tabelle IV hervorgeht, bei den einzelnen Versuchsreihen, die zu verschiedenen Zeiten nach der Sensibilisierung angestellt wurden, nicht unerheblich.

In der nächsten Versuchsreihe $V$ sind die Tiere gleichfalls mit steigenden Dosen Serum vorbehandelt (anaphylaktisiert) worden. Es handelt sich um eine kleine Versuchsreihe von 3 Tieren, bei der die Schutzimpfung ausnahmsweise wieder intravenös angestellt ist. Der Versuch zeigt, daB selbst der Dosis letalis nahekommende Serumgaben schlecht schützen.

Beim Versuch VI bis VII handelt es sich um Meerschweinchen, die einmal mit großen Serumdosen $\left(10^{\mathrm{cem}}\right)$ vorbehandelt wurden. Derartige Tiere sind gegen die subkutane Reinjektion lange Zeit unempfindlich. Die Tiere wurden in Serie VI 3 Wochen nach der Sensibilisierung mit fallenden Dosen Serum subkutan reinjiziert und darauf, 20 Stunden später mit 0.2 subdural oder $0.5 \mathrm{~cm}$ intravenös nachgeprüft. Wie aus der Tabelle VI hervorgeht, war der bei diesen Tieren erzielte Schutz ein sehr schwankender. Diese Beobachtung steht im Einklang mit den Angaben Weils, daß zu Erzeugung der Antianaphylaxie bei Tieren, die mit großen Dosen sensibilisiert sind, größere Serumdosen erforderlich sind, als bei Tieren, die mit kleinen Serumdosen vorbehandelt werden.

Einen etwas besseren Schutz erzielten wir bei dieser Tierserie durch die intravenöse Schutzimpfung (siehe Tabelle VII). Allerdings können wir trotzdem die intravenöse Schutzimpfung nicht empfehlen. Wie aus den Versuchsergebnissen hervorgeht, erkrankten schon bei dieser Vorbehandlung von den 5 Tieren 4 schwer und gingen sogar zum Teil (2) akut ein, darunter eins von den Tieren, welches die kleinste Serumdosis erhalten hatte. 
Tabelle V.

Meerschweinchen, mehrmals vorbehandelt $(0.01-0.1-1.0 \mathrm{~cm})$ subkutan.

Reinjektion: intravenös (fallende Dosen). - Prüfung: intravenös $\left(0.5^{\mathrm{cm}}\right)$.

\begin{tabular}{|c|c|c|c|c|}
\hline \multicolumn{5}{|c|}{ Reinjektion nach 3 Wochen (bzw. 6 Tage nach der letzten Injektion): } \\
\hline & Dosis (in $\mathrm{ccm}$ ) & & & Prüfung nach 20 Stunden \\
\hline 1. & $0 \cdot 5$ & Yee. 511: & $\div 6^{\prime}$ & 9 \\
\hline 2. & 0.25 & $\Rightarrow 512:$ & $x \times x$ & $x \times x$ \\
\hline 3. & 0.1 & , $513:$ & $x ?$ & $\times ?$ \\
\hline
\end{tabular}

Tabelle VI.

Meerschweinchen, $1 \mathrm{mal}$ vorbehandelt mit $10.0 \mathrm{~cm}$ normalem Pferdeserum subkutan.

Reinjektion: subkutan (fallende Dosen). - Prüfung: subdural $\left(0 \cdot 2^{\mathrm{cm}}\right)$, oder intravenös $\left(0.5^{\mathrm{ccm}}\right)$.

\begin{tabular}{|c|c|c|c|c|c|c|c|}
\hline \multicolumn{6}{|c|}{ Reinjektion nach 3 Wochen: } & $\begin{array}{l}\text { Prüfung } \\
\text { subdural }\end{array}$ & $\begin{array}{c}\text { Prüfung } \\
\text { intravenös }\end{array}$ \\
\hline 1. & Mee. 1 & - & Dosis & $1.0 \mathrm{~cm}$ & Mee. $450: \times$ ? & $x$ & $\emptyset$ \\
\hline 2. & - & Mee. 2 & & & , 451: $\times$ & $\mathfrak{b}$ & $\times x$ \\
\hline 3. & Mee. 3 & - & " & $0.5 "$ & " 452:0? & $x \times$ & 6 \\
\hline 4. & 一 & Mee. 4 & & & " 453: 0 & $\mathfrak{g}$ & $t$ \\
\hline 5. & Mee. 5 & - & " & 0.25, & , 454:0? & $x$ & $\mathfrak{b}$ \\
\hline 6. & - & Mee. 6 & & & „, 455: 0? & g & $x \times$ \\
\hline 7. & Mee. 7 & - & " & $0.1 \#$ & \# 456:0? & $x$ & $\emptyset$ \\
\hline 8. & - & Mee. 8 & & & "457:0? & $\mathfrak{\emptyset}$ & $x \times x$ \\
\hline 9. & Kontr. 1 & - & Kon & trollen: & "458: - & $x \times(x)$ & 6 \\
\hline 10. & - & Kontr. 2 & & & "459: - & g & $+6^{\prime}$ \\
\hline
\end{tabular}

Tabelle VII.

Meerschweinchen, 1 mal vorbehandelt mit $10.0 \mathrm{~cm}$ normalem Pferdeserum subkutan.

Reinjektion: intravenös (fallende Dosen). - Prüfung: subdural $\left(0 \cdot 2^{\mathrm{cem}}\right)$.

\begin{tabular}{|c|c|c|c|c|}
\hline \multicolumn{5}{|c|}{ Reinjektion nach 3 Wochen: } \\
\hline & Dosis (in $\mathrm{cem}$ ) & & & Prüfung nach 20 Stunden \\
\hline 1. & 0.5 & Mee. 460 & $+10^{\prime}$ & $\emptyset$ \\
\hline 2. & 0.25 & $" 461$ & $x \times x$ & 0 ? \\
\hline 3. & 0.25 & $\Longrightarrow 462$ & $x$ & $x$ \\
\hline 4. & 0.1 & " 463 & $x \times x$ & $x \times$ \\
\hline 5. & 0.1 & , 464 & $\div 5^{\circ}$ & (Kontrolle: s. Tabelle VI) \\
\hline
\end{tabular}


Wir haben dann noch die intrakutane Serumapplikation zur antianaphylaktischen Schutzimpfung herangezogen, und zwar in zwei Versuchsreihen (VIII bis IX), bei denen die Tiere 4 Wochen vorher mit $0.01 \mathrm{~cm}$ sensibilisiert waren. Die intrakutane Schutzimpfung wurde in der Weise vorgenommen, daB in der Serie VIII den Meerschweinchen fallende Dosen Serum intrakutan mit feịner Kanüle appliziert wurden.: Vor der Injektion sind an den zu injizierenden Stellen die Haare mit der Schere und ,Rasito" entfernt worden. An einer Hautstelle wurde regelmäBig $0.2 \mathrm{~cm}$ injiziert. $\mathrm{Da}$ die Serumdosen zwischen 0.2 und $1 \cdot 6^{\mathrm{cm}}$ schwankten, erhielten die verschiedenen Tiere, je nach der Dosis, 1 bis 8 Pusteln gesetzt. Die Prüfung erfolgte nach 24 Stunden in der üblichen Weise, indem $0.5^{\mathrm{ccm}}$ Pferdeserum intravenös injiziert wurde. Einen guten Schutzerfolg sahen wir nur bei dem Tiere, das mit $1.6 \mathrm{~cm}$ intrakutan am Tage vorher reinjiziert war. Bei den Tieren die mit 0.8 bzw. $0.4 \mathrm{ccm}$ schutzgeimpft waren, war der Erfolg der Impfung nur ein geringer, beide Tiere erkrankten schwer.

Tabelle VIII.

5 Meerschweinchen, am 9.IV. 14 mit $0.01 \mathrm{~cm}$ normalem Pferdeserum subkutan vorbehandelt

(nach 4 Wochen):

\begin{tabular}{|c|c|c|}
\hline & $\begin{array}{l}\text { Prüfung nach } \\
24 \text { Stunden }\end{array}$ & Erfolg \\
\hline $\begin{array}{l}\text { Mee. Nr. } 33 \text { am } 8 . \text { V. } 140.2 \mathrm{ccm} \text { norm. } \\
\text { Pferdeserum ( } 1 \text { Pustel in trakutan) } \\
\text { Mee. Nr. } 34 \text { am } 8 \text {. V. } 140.4^{\mathrm{ccm}} \text { norm. } \\
\text { Pferdeserum ( } 2 \text { Pusteln in trakutan) } \\
\text { Mee. Nr. } 35 \text { am } 8 \text {. V. } 140.8^{\mathrm{ccm}} \text { norm. } \\
\text { Pferdeserum (4 Pusteln in trak utan) } \\
\text { Mee. Nr. } 36 \text { am 8. V. } 141.6 \text { com norm. } \\
\text { Pferdeserum (8 Pusteln intrakutan) } \\
\text { Mee. ungezeichnet (bleibt ohne Vor- } \\
\text { behandlung) }\end{array}$ & $\begin{array}{c}\text { Alle Tiere } \\
\text { erhalten } \\
\text { am } 9 . \text { V. } 14 \\
\text { je } 0.5 \text { com } \\
\text { norm. Pferde. } \\
\text { serum } \\
\text { intravenös }\end{array}$ & $\begin{array}{c}+5^{\prime} \\
\text { schwer kraok, fast agonal, } \\
\text { erholt sich langsam. } \\
\text { schwer krank, erholt sich. } \\
\text { keine deutlichen Symptome, } \\
\text { munter. } \\
+3^{\prime} !\end{array}$ \\
\hline
\end{tabular}

In der nächsten Serie IX ist von uns geprüft worden, wann nach der intrakutanen Schutzimpfung eine sichere Antianaphylaxie eintritt. Wie aus der Tabelle IX hervorgeht, ist nach der intrakutanen Schutzimpfung von 1.2 bzw. $1.6^{\mathrm{cem}}$ der absolute Schutz erst nach 24 Stunden sicher erreicht. Aber schon nach 3 Stunden kommen die Tiere mit dem Leben davon, während sie nach 1 bis 2 Stunden noch akut eingehen oder doch schwer erkranken und im Laufe der nächsten Tage verenden. Versuch IXb zeigt dann, daB der Schutz bereits $n$ ach 4 Stunden recht erheblich ist.

Die überempfindlichen Tiere zeigten im übrigen nach der intrakutanen Reinjektion deutliche anaphylaktische Erscheinungen, die im allgemeinen nur ein wenig später einsetzten wie bei der subkutanen Reinjektion. 

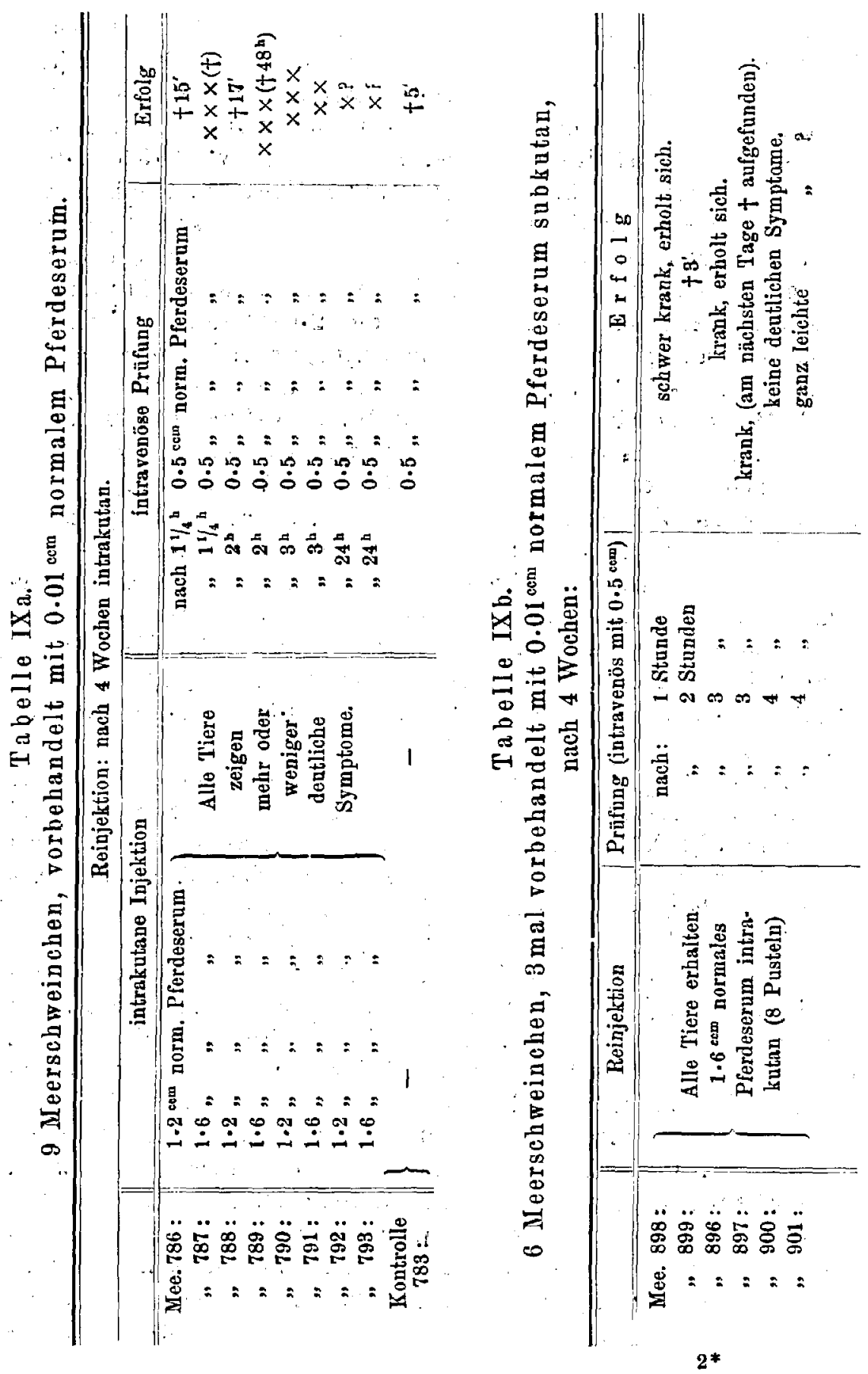
Zusammenfassend ergibt sich aus unseren Versuchen, daB sich bei den hochüberempfindlichen Meerschweinchen durch die subkutane (bzw. intrakutane) Seruminjektion von absolut ungefährlichen Serumdosen ein wirksamer Sthutz gegen die nachfolgende intravenōse Injektion einer mehrfach tödlichen Serumdosis erzielen läßt. Serumgaben von 0.5 bis $1 \cdot 0^{\mathrm{ecm}}$, die selbst bei hochüberempfindlichen Meerschweinchen nur leichte, selten deutliche anaphylaktische Erscheinungen machten, ergaben einen genügenden Schutz gegen die (zweiund mehrfach) tödliche Dosis. Nur bei den besonders hochanaphylaktischen Tieren war die Anwendung von $2.0 \mathrm{cem}$ Serum erforderlich, das dann allerdings schon bei der Schutzimpfung zum Teil schwere Überempfindlichkeits-Reaktionen auslöste. Zur intrakutanen Schutzimpfung war $1.6^{\mathrm{com}}$ notwendig, zur intravenösen 0.1 bis $0.2^{\mathrm{ccm}}$, eine Dosis, die an und für sich schon die Tiere schwer erkranken ließ oder gar tötete.

Letztere Injektionsweise können wir daher für die Prophylaxe aus diesem Grunde nicht empfehlen. Auch die intrakutane Serumapplikation dürfte in praktischer Beziehung hinter der subkutanen zurückstehen, da einmal die Injektion an mehreren Stellen auch beim Menschen vorgenommen werden müBte und sicher wegen des nachfolgenden Juckreizes weniger angenehm sein wird. Wir möchten daher für die Anwendung beim Menschen zur Erzielung eines antianaphylaktischen Schutzes die subkutane Injektion von 0.5 bis $1.0 \mathrm{ccm}$ Serum rorschlagen.

Eine derartige Schutzimpfung bäme ror der Injektion gröBerer Serumdosen in Betracht 1 . bei allen Personen, die früher schon einmal mit Serum behandelt worden sind, und 2. bei den Menschen, die an irgend einer „Idiosynkrasie" oder "Diathese" leiden. Sie sollte 3. allgemein angewandt werden, wenn die Applikation grober Serumdosen oder eine intravienöse oder intraspinale Seruminjektion beabsichtigt ist.

Da ein gewisser anaphylaktischer Schutz erst 3 bis 4 Stunden nach der subkutanen Injektion zu erwarten ist, so $m u B$ natürlich bei allen ernsten Erkrankungen, z. B. bei einer schweren Diphtherie, wo die möglichst schnelle Seruminjektion unbedingtes Erfordernis ist, a uf die Erzielung dieses anaphylaktischen Schutzes verzichtet werden. Man könnte aber selbst in diesen Fällen vielleicht eine erste, subkutane Injektion und nach einigen Stunden eine zweite, intravenöse Seruminjektion vornehmen. Weiter glauben wir, in Anbetracht des Umstandes, daß eine Serumüberempfindlichkeit öfters bei Personen angetroffen wird, die weder früher mit Serum behandelt sind, noch sonst verdächtig erscheinen, vorschlagen zu dürfen, daB sogar in allen nicht dringenden Fällen möglichst generell von der antiana- 
phylaktischen Schutzimpfung Gebrauch gemacht wird. Ein Nachteil in der Heilwirkung des Diphtherieserums bei leichten oder nur verdächtigen Erkrankungen wird dadurch kaum verursacht werden, wenn der Arzt zunächst nur $\mathbf{0 . 5} \mathrm{cm}$ bis $1.0^{\mathrm{ccm}}$ und einige Stunden später den Rest der Heildosis des Serums injiziert. Sollte wider Erwarten einmal eine hochgradige Uberempfindlichkeit vorliegen, so wird unter Umständen schon die im AnschluB an die erste Injektion nach kurzer Zeit auftretende "lokale" Reaktion den Arzt aufmerksam machen und ihn reranlassen, bei den weiteren Seruminjektionen vorsichtig vorzugehen. -

Während wir mit unseren Untersuchungen beschäftigt waren, hat Eichholz über Versuche berichtet, die Anti-Anaphylaxie durch 01trockenserum, bei dem eine möglichst langsame Resorption des Serums erwartet wurde, 'zu erzielen.

\section{Tabelle $\mathrm{X}$.}

Vorbehandelte Meerschweinchen.

Versuch I: am 12. XII. 13.

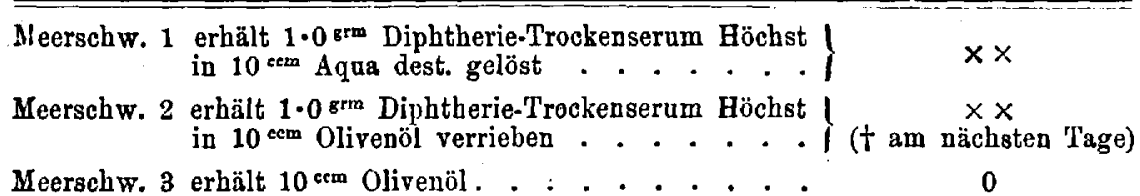

Versuch II: am 13. XII. 13.

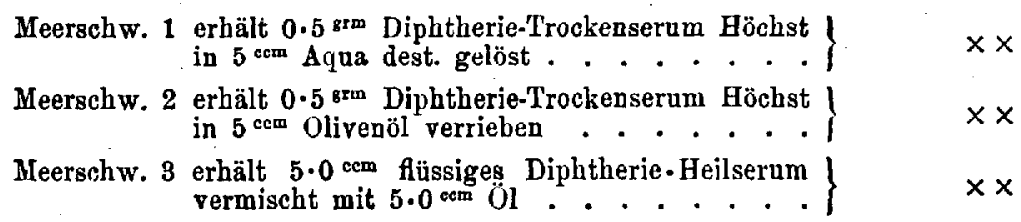

Bei der Nachprüfung der Eichholzschen Versuche kamen wir, ebenso wie Joseph, zunächst zu wenig günstigen Resultaten. Da uns das Eichholzsche. Originalserum (der Firma Merck) anfangs nicht zur Verfügung stand, haben wir die ersten Versuche mit einem uns freundlichst von den Höchster Farbwerken überlassenen Trockenserum angestellt. Wir gingen in der Weise vor, daß wir das Trockenserum mit $O 1$ verrieben und dann das Gemisch den Tieren subkutan injizierten; einigen KontrollTieren gaben wir die gleiche Mlenge Trockenserum in Aqua destillata gelöst, gleichfalls subkutan. Wie aus der Tabelle X hervorgeht, erkrankten 
bei zwei in dieser Weise angestellten Versuchen die Tiere, welche das in Ol verriebene Trockenserum erhalten hatten, gerade so schwer, wenn auch vielleicht etwas später, wie die Kontroll-Tiere. Auch andere Suspensionsmittel, z. B. Kakaobutter, Gelatine usw., verzögerten die Resorption des Trockenserums in keiner Weise. Etwas günstigere Resultate erhielten wir nach Anwendung des Merckschen Original-Präparates, das uns von der Firma später in liebenswürdiger Weise zur Verfügung gestellt wurde. Die bessere Wirkung des Merckschen Ol-Trockenserums dürfte wohl in der feineren Verreibung des Serums mit dem Öl beruhen, die nach den Angaben der Fabrik in folgender Weise bewirkt wird:

Das ,injektionsfertige Trockenserum". wird nach einem durch das D. R.P. Nr. 233693 geschützten Verfahren hergestellt, indem man genuines Immunserum unter sterilen Kautelen bei niederer Temperatur trocknet, das Trockenserum sehr fein mahlt und das so entstandene staubfeine Pulver in sterilem Fett aufschwemmt. Das injektionsfertige Trockenserum ist bei gewöhnlicher Temperatur fest, bei Körpertemperatur aber dünnflüssig genug, um mit den gewöhnlichen Asbeststempelspritzen leicht aufgesogen und eingespritzt werden zu können. Es ist dank seiner absoluten Wasserfreiheit unbegrenzt haltbar und kann niemals der bakteriellen Zersetzung asheimfallen." -

Bezüglich der "Indikationen" wird in dem Prospekt der. Firma gesagt: „Uneingeschränkt indiziert ist das injektionsfertige Trockenserum überall da, wo keine Gefahr im Verzuge ist - also in erster Linie bei allen prophylaktischen Serumeinspritzungen - und dort, wo das Bestehen von Serumanaphylaxie vermutet wird ..."

Die „Gebrauchsanweisung" lautet: „Da der Inhalt der Ampullen bei gewöhnlicher Temperatur fest ist, so ist darauf zu achten, daß er bei der Einspritzung gut körperwarm ist.

Die Fläschchen 'sind vor dem Gebrauch durch Einlegen in Wasser von 40 bis $45^{\circ}$ auf Körper-Temperatur zu erwärmen, daun abzutrocknen, umzuschütteln und durch Abbrechen des Halses an der Feilmarke zu öffnen. Die Einspritzung (subkutan oder. intramuskulär) erfolgt mit einer gewöhnlichen Asbeststempelspritze mit weiter Kanüle.

Die Spritzen werden nach dem Gebrauch mit Äther gereinigt." -

Wie aus der Tabelle XI hervorgeht, tritt nach der Injektion von groBen Dosen (10 bis $15^{\mathrm{cm}}$ ) des Merckschen Ö-Trockenserums bei überempfindlichen Tieren schwere Anaphylaxie ein, die kaum geringer ist wie die nach'der Injektion gleich groBer Mengen gelösten Trockenserums oder flüssigen Diphtherieserums. Etwas günstiger waren die Resultate für das Mercksche O1-Trockenserum bei $\cdot d e r$ Verwendung kleinerer Serumdosen $\left(2 \cdot 0\right.$ bis $\left.5.0^{\mathrm{cm}}\right)$. Dabei hatten wir auch den Eindruck, daB die Krankheitserscheinungen nach der (intraperitonealen und subkutanen) Applikation des Merckschen Öl-Trockenserums später eintraten als nach gelöstem Höchster Trockenserum und flüssigen Diphtherieserum. 
Tabelle XI.

Prüfung des 0l-Trockenserums an anaphylaktischen Tieren,

\begin{tabular}{|c|c|c|c|c|c|c|}
\hline Serumart und -Dosi & & 总 & $\ddot{8}$ & 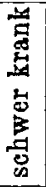 & 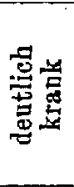 & 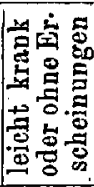 \\
\hline \multicolumn{7}{|l|}{ A. Intraperitoneale Reinjektion: } \\
\hline 1. Mercksches Öl.Trockenseram & . . . . $5^{\mathrm{ccm}}$ & 3 & 1 & 1 & - & 1 \\
\hline 2. Gelöstes Höchster Diphtherieserum & . $0.5^{\mathrm{gra}}$ in 5, & 5 & 3 & 1 & - & 1 \\
\hline 3. Normal.Pferdeserum (flüssig) . & $\therefore . .5$, & 6 & 2 & 4 & $\therefore$ & $\because$ \\
\hline \multicolumn{7}{|l|}{ B. Subkutane Reinjektion: } \\
\hline 1. Mercksches Öl-Trockenseruun . . & $\begin{array}{r}\cdot . \quad \cdot 15^{\mathrm{com}} \\
10^{\prime \prime} \\
5 \% \\
2 "\end{array}$ & $\begin{array}{l}1 \\
5 \\
+5 \\
\mathbf{2}\end{array}$ & $\begin{array}{l}1 \\
1 \\
\dot{.}\end{array}$ & $\begin{array}{l}\dot{3} \\
3 \\
1 \\
\dot{.}\end{array}$ & $\begin{array}{l}\dot{1} \\
\dot{1}\end{array}$ & $\begin{array}{l}\dot{5} \\
\dot{4} \\
2\end{array}$ \\
\hline 2. Gelöstes Höchster Diphtherieserum & 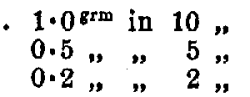 & $\begin{array}{l}2 \\
7 \\
4\end{array}$ & $\dot{1}$ & $\begin{array}{l}2 \\
3 \\
.\end{array}$ & $\begin{array}{l}\dot{3} \\
2\end{array}$ & $\dot{2}$ \\
\hline 3. Normal-Pferdeserum (flüssig) . & 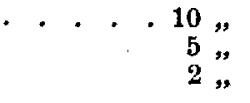 & $\begin{array}{l}2 \\
5 \\
2\end{array}$ & $\vdots$ & $\begin{array}{l}2 \\
2 \\
-\end{array}$ & $\dot{2}$ & $\dot{1}$ \\
\hline
\end{tabular}

Nach diesen Versuchsergebnissen dürfte die Anwendung des Merckschen Trockenserums. überall da, wo keine Gefahr im Verzuge ist, z. B. bei prophylaktischen Injektionen, zu denen nur geringe Serumdosen notwendig sind, den Indikationen der Fabrik entsprechend, nicht unberechtigt sein, ebenso in den Fällen, wo das Bestehen einer Serumanaphylaxie ver. mutet wird. Vorauszusetzen bleibt dabei natürlich, daB die spezifische antitoxische Wirkung des Heilserums durch die Aufschwemmung in dem sterilen $\mathrm{Ol}$ nicht gestört wird, was nach den Untersuchungen von Eich hola nicht der Fall sein soll.

Allerdings müssen wir noch die Frage offen lassen, ob sich die Injektion des Öl-Trockenserums in der Praxis nicht als zu umständlich erweisen wird, weil die Fläschchen vor dem Gebrauch zunächst durch Einlegen in Wasser von 40 bis $45^{\circ}$ gelöst werden müssen, und das flüssig gemachte Serum in den Spritzen sehr leicht wieder erstarrt, wodurch für den praktischen Arzt unter Umständen unliebsame Verzögerungen eintreten können. Auch ist die Reinigung der Spritzen dadurch kompliziert, daß sie nach dem Gebrauch jedesmal mit Äther gereinigt werden müssen.

Bei der Gelegenheit wollen wir noch einige Versuche erwähnen, bei denen wir zwecks Verzögerung der Resorption dem Serum Adrenalin zugesetzt haben. 
Die unmittelbare Wirkung des Adrenalins besteht bekanntlich in einer Anämisierung der Gewebe durch Kontraktion der Kapillaren und der mittleren BlutgefäBe in der Nähø der Applikationsstelle, die eine Drucksteigerung im GefäBsystem des Körpers zur Folge hat. Die allgemeine Wirkung des Adrenalins ist also entgegengesetzt dem beim anaphylaktischen Shock wirksamen Gift, das nach Tierexperimenten zu einem Sinken des Blutdrucks führt.

Ferschiedene Autoren haben daher das Adrenalin zur Abschwächung des anaphylaktischen shocks im Tierversuch geprüft. Die Ergebnisse waren bei Hunden verschieden (Biedl und Kraus, Seott), bei Kaninchen (Scott) und Meerschweinchen (Loewit, Friedberger und Galambos) günstig.

Im Gegensatz zu diesen Autoren haben wir das Adrenalin verwandt, um eine lokale Wirkung zu erzielen. In der Tat gelang es uns anfangs ziemlich regelmäßig, durch die gleichzeitige Injektion von verhältnismäBig groBen Dosen Adrenalin die anaphylaktischen Krankheitserseheinungen bei den Meerschweinchen nach der Seruminjektion herabzusetzen. Am günstigsten wirkten bei den Meerschweinchen groBe, an der Dosis letalis liegende Adrenalin-Dosen $(0.3$ bis $0.5 \mathrm{~cm}$ Adrenalin $1 / 3000)$. Bei noch größeren Dosen Adrenalin traten oft schwere Krankheitserscheinungen auf, die häufig, aber nicht regelmäBig zum Tode führten. Leider konnten wir bei der Wiederholung der Versuche nach Aufbrauch des zuerst benutzten Präparates die anfangs beobachteten günstigen Erfolge bei mehreren neuen Präparaten nicht wieder konstatieren. Wir müssen es vorläufig dahingestellt sein lassen, ob diese Differenz in den Versuchsresultaten durch die ungleichmäBige Empfänglichkeit der Tiere, oder durch die verschiedene Wirksamkeit der Präparate bedingt war.

Die Tatsache, daB bei der Anaphylaxie das fremdartige EiweiB das schädigende Agens ist, hat zu dem bereits oben erwähnten Bestreben geführt, "hochwertige" Sera zu gewinnen, um so einen möglichst hohen Antitoxingehalt in möglichst geringen Serummengen zu erhalten. Derartige hochwertige Sera kann man natürlich nicht einfach dadurch herstellen, daß man die Sera konzentriert, denn bei solchen Eindickungen wird auch der EiweiBgehalt des Serums erhöht, wodurch der erstrebte Vorteil wieder verloren geht. BestimmungsgemäB werden daher alle in Deutschland zugelassenen Sera auf ihren EiweiBgehalt untersucht, und alle Sera zurückgewiesen, welche mehr als 12 Prozent Eiweiß enthalten.

Weiter hat man dann versucht, dem Pferdeserum durch physikalische und chemische Methoden alle diejenigen Eiweibstoffe zu entziehen, welche als Träger des Antitoxins nicht in Frage kommen. Wir wollen hier auf die verschiedenen Versuche nicht năher eingehen, sondern nur bemerken, daß diese „Serumreinigung“ (Literatur siehe bei v. Behring), d. h. die Entfernung der überflüssigen Eiweißstoffe, auf nicht unerhebliche Schwierig- 
keiten gestoBen ist. Es liegt das hauptsächlich daran, daB diejenigen Teile des SerumeiweiBes, welche die Träger der antitoxischen Wirkung sind ${ }^{1}$, auch gleichzeitig bei der Anaphylaxie eine groBe Rolle spielen. v. Behring gibt allerdings an, da $B$ es ihm gelungen sei, die giftige (anatoxische) Wirkung des Serums durch ,Serumreinigung" nach einem bestimmten Verfahren um das achtfache herabzusetzen. Er sagt jedoch über seine Methode, da $B$ der Aufwand an Arbeitskraft und Geldmitteln dabei so gro $B$ war, daB man sich für die Praxis voraussichtlich mit Präparaten von stärkerer relativer Anatoxizität wird begnügen müssen.

In Deutsehland wird nach Boehncke (a. a. 0.) von dem Serumlaboratorium Ruete-Enoch in Hamburg ein gereinigtes (,eiweißarmes") Diphtherieserum in den Verkehr gebracht; das Serum ist der staatlichen Kontrolle unterstellt. Auch in anderen Ländern, z. B. in RuBland und in Nordamerika, werden solche "gereinigten" Heilsera hergestellt und vertrieben. Herr Dr. Blumenthal (Moskau) war so liebenswürdig, uns eine Probe des in seinem Institut hergestellten gereinigten Heilserums 2u senden, zugleich mit Proben desselben Serums vor seiner Reinigung. Die „Reinigung" des Serums war nach dem amerikanischen Verfahren von Gibson und Banzaf vorgenommen und zwar nach einer Modifikation von Sarkatoff ${ }^{2}$ in folgender Weise:

,Zuerst wird das native Serum 12 bis 24 Stunden lang auf $56^{\circ} \mathrm{C}$ erwärmt. Sodann wird es abgekühlt, mit Wasser verdünnt und mit Kochsalz gesättigt, hierauf filtriert, wobei im Bodensatz die nicht antitoxischen Eiweilskörper, im Filtrat dagegen die gelösten antitoxischen Globuline enthalten sind. Letztere werden mit schwefelsaurem Ammonium gefällt, und der Globulinniederschlag behufs Entfernung der Salze (Natr. chlorat. und Ammoniumsulf.) der Dialyse unterzogen. Nach der Dialyse filtriert man das Serum durch Tonkerzen und prüft es auf Sterilität. Bei dieser Behandlung des Serums werden 60 bis 65 Prozent (durchschnittlich 64 Prozent) der inaktiven Eiweibsubstanzen entfernt, und es resultiert eine vier- bis fünffache Konzentrierung des Heilserums. Bei einer derartigen Reinigung des Serums gelingt. es, minderwertige Sera so weit zu konzentrieren, daB sie sich in hochwertige verwandeln. So demonstrieren Ph. M. Blumenthal und J. D. Sarkatoff ein Serum, daB in nativem Zustande einen Heilwert von $150 \mathrm{~A}$. E. pro Kubikzentimeter besab und bei einem spezifischen Gewicht von 1.032 in einer Heildosis von 1000 A. E. $0.455^{\mathrm{grm}}$ Eiweilstoffe enthielt. Nach dem obigen Verfahren behandelt, wies das gereinigte Serum nunmehr einen Heilwert von $700 \mathrm{~A}$. E. auf und enthielt bei einem spezifischen Gewicht von 1.040

${ }^{1}$ Kammann zeigte, daB mit Serumalbumin oder Serumglobulin sensibilisierte Meerschweinchen gegen beide Fraktionen anaphylaktisch sind. Solange es also nicht möglich ist, die antitorische Wirkang ganz rom Serumeiweiß zu trennen, wird eine gewisse Anaphylaxiegefahr bestehen bleiben.

2 Berliner klin. Wachenschrift. 1913. Nr. 23. 
in einer Heildosis von 1000 A. E. nur noch $0.164 \mathrm{grm}$ EiweiBstoffe. Die Konzentrierung gewährt nicht nur die Möglichkeit weit geringere Mengen, die ja nur unnützen Ballast abgeben, einzuführen, sondern auch dank der Steigerung des Heilwerts der Sera eine viel kleinere Flüssigkeitsmenge zu injizieren."

Die Angaben der uns freundlich übersandten Sera lauteten dahin, daB das "native" Serum etwa 125 bis 150 fach, das "gereinigte" Serum 600 bis 650 fach sei. Wie die auf der Abteilung vorgenommene Nachprüfung ergab, war das erste Serum etwa 150 fach, das letztere etwas über $650 \mathrm{fach}$.

Mit beiden Serumproben wurde nummehr an anaphylaktischen Meerschweinchen die EiweiBgiftigkeit des Serums festgestellt. Wie sich aus den folgenden Protokollen ergibt; war das gereinigte Serum, trotzdem es über $4 \mathrm{mal}$ soviel Antitoxin enthielt, nicht toxischer als das native Serum.

$$
\text { Tabelle XII. }
$$

Subkutan mit $0.01 \mathrm{~cm} 3$ mal vorbehandelte Meerschweinchen. Intravenöse Reinjektion.

\begin{tabular}{|c|c|c|c|c|c|c|c|c|}
\hline Nr. & $\left|\begin{array}{c}\text { Ge- } \\
\text { wicht }\end{array}\right|$ & & & 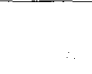 & . & & : & : \\
\hline I & 210 & Normales & Pfe & rdeseru & $\mathbf{m}$ & 0.05 & leicht krank? & davon \\
\hline II & 220 & Serum no & oska & , nati & $v^{*}:$. & 0.05 & schwer krank & $+20^{\prime}$ \\
\hline III & 230 & , &, & , & . . & 0.05 & , & davon \\
\hline IV & 220 & , & ,* & $"$ & , . & 0.025 & , & $+30^{\prime}$ \\
\hline $\mathbf{V}$ & 220 & $"$ & , & $\because$ &.$\therefore$ & 0.025 & ", & davon \\
\hline VI & 230 & , & •" & " & & 0.025 & ," & davon ${ }^{\circ}$ \\
\hline VII. & 230 & , & , & , & $:$. & 0.01 & leicht krank & , \\
\hline VIII & 230 & ," & , & ,, &. & 0.01 & ," & ", \\
\hline IX & 220 & „gereinigt & les"6 & Serum & Moskau & 0.05 & krank, erholt sich & , \\
\hline$x$ & 230 & , & & , & , & 0.05 & schwer krank & $+4^{\prime}$ \\
\hline XI & 235 & ” & & $\therefore$ & , & 0.025 & $\cdots$, & davon \\
\hline XII & 230 & " & & ; & , & 0.025 & & $+15^{\prime}$ \\
\hline XIII & 235 & " & & ," & , & 0.01 & krank & davon \\
\hline XIV & 230 & $"$ & & " . & $\because$ & 0.01 & , & $\therefore "$ \\
\hline
\end{tabular}

Wenn also ans unseren Versuchen auch hervorgeht, daB das von uns geprüfte "gereinigte" Serum trotz der Konzentration der Antitoxine keine stärkere anatoxische Wirkung ausübte als das native Serum, so hat sich nach den Erfahrungen von Egis und Kolli seine Anwendung in der Praxis aus anderen Gründen doch wenig empfohlen. Das Serum hat zwar auch dort die gleiche kurative Kraft wie das native gezeigt, auch ist die Zahl der Serumerkrankungen und die Intensität der Erscheinungen bedeutend geringer gewesen wie beim nativen Serum, aber es hat sich heraus- 
gestellt, daB seine Injektion ziemlich. schmerzhaft ist, vielleicht infolge ungenügender Entfernung des Ammoniumsulfates.

Auch Versuche von Boehncke und Mouriz zeigten, daß die Anaphylaxiegefahr im Tierversuch bei Anwendung der gereinigten Sera ver. ringert ist.

Bei der Gelegenheit mōchten wir noch auf die alte Erfahrung hinweisen, daß ältere (abgelagerte) Sera weniger anaphylaktisch wirken als frische. Schon vor Jahren hat Bujwid diese Beobachtung gemacht. In Deutschland ist übrigens durch die staatliche Prüfung, zu der ganz frische Sera wegen ihres meist noch schwankenden Antitoxingehaltes kaum eingesandt werden, für ein bestimmtes Alter der Sera gesorgt. $\mathrm{DaB}$ aber noch mehrere Jahre alte Sera Anaphylaxie erzeugen können, zeigt folgender Versuch, den der eine von uns (0.) bei seinen ersten Anaphylaxieversuchen angestellt hat (siehe Tabelle XIII). Es geht aus diesem (bisher

Tabelle XIII.

Sera von verschiedenem Alter.

\begin{tabular}{|c|c|c|c|c|c|c|c|c|c|}
\hline Serum , & \multicolumn{3}{|c|}{11 Nr. 1 Jahre alt } & \multicolumn{3}{|c|}{$2 \stackrel{\text { Nr. } 2}{\text { Jahre alt }}$} & \multicolumn{3}{|c|}{\begin{tabular}{|l|l|} 
frisch & $\begin{array}{l}\text { Nr. } 3 \\
\text { zugelassenes } \\
\text { Serum }\end{array}$ \\
\end{tabular}} \\
\hline $\begin{array}{c}\text { Serumdosis } \\
\text { bei der } \\
\text { intraperitonealen } \\
\text { Reinjektion }\end{array}$ & $\stackrel{+}{+}$ & 层 & 祮 & 蓎 & $\begin{array}{l}\text { 를 } \\
\text { 톨 }\end{array}$ & $\begin{array}{l}\overrightarrow{\mathrm{g}} \\
\stackrel{\mathrm{g}}{\mathrm{g}} \\
\mathrm{g}\end{array}$ & 苔 & 范 & 营 \\
\hline $5.0 \mathrm{ccm}$ & 0 & 2 & 0 & 1 & 1 & 0 & 1 & 1 & 0 \\
\hline $2 \cdot 0 "$ & 0 & 3 & 1 & 0 & 1. & 0 & 1 & 1 & 0 \\
\hline 0.5, & $\mathbf{0}$ & 2 & 1 & 0 & 1 & 0 & 0 & 2 & 0 \\
\hline & 0 & 7 & 2 & 1 & 3 & 0 & 2 & 4 & 0 \\
\hline
\end{tabular}

nicht publizierten) Versuche hervor, daB ein 11 Jahre altes Serum bei der intraperitonealen Reinjektion anaphylaktischer Meerschweinchen noch Krankheitserscheinungen auslöste, aber es tötete nicht mehr in den Dosen, die bei frischen oder 2 Jahre alten Seris noch tödlich wirkten:' Zu fast dem gleichen Resultat ist Boehncke bei neueren Versuchen gelangt. Auch er konnte bei 2 Jahre alten Seris eine gewisse Abschwächung der Giftwirkung bei der Reinjektion feststellen. Eine Abschwächung der sensibilierenden Wirkung durch das Alter war im übrigen nicht vorhanden. 


\section{Zusammenfassung.}

Nach Besprechung der beim Menschen beobachteten schweren Zufälle nach Heilseruminjektionen wird über Versuche an anaphylalitischen Meerschweinchen berichtet, durch die festgestellt werden sollte, von welchen, möglichst kleinen Serumdosen und nach welcher Zeit ein antianaphylaktischer Schutz zu erwarten ist.

Die Ergebnisse der Versuche und die daran geknüpften Vorschläge für die Prophylaxe beim Menschen -sind auf S. 20 bis 21 zusammengefaBt.

Im. AnschluB daran werden einige Versuche über die Verhütung der Anaphylaxie durch die Anwendung von Öltrockenserum, Serum mit Adrenalinzusatz, gereinigtem und abgelagertem Serum mitgeteilt.

\section{Literatar-Verzeichnis.}

Ausführliche Angaben finden sich bei:

1. v. Pirquet u. Schick, Die Serumkrankcheit. Leipzig u. Wien 1905.

2. Kr Otto, Anaphylaxie und Serumkrankheit. Handbuch von Kolle.Wassermann. 1909. Erg.Bd. II. 1. Anfl.

3. R. Doerr, Allergie und Anaphylaxie. Ebenda. 1913. Bả. II. 2. Aufl.

Weitere Literaturstellen, die in obigen Arbeiten nicht angegeben sind:

Bauer, Münchener med. Wochenschrift. 1911.

จ. Behring, Einführung in die Lehre von der Bekämpfung der Infektionskrankheiten. Berlin 1912.

Derselbe, Hamburg. medizin. Überseehefte. 1914.

Bessau, Centralblatt f. Bakteriologie. Orig. Bd. LXXIV.

Billard et Barbes, Ebenda. Ref. Bd. LIX.

Boehncke, Deutsche med. Wochenschrift. 1914. Nr. 11.

Boehncke y Monriz, Centralblatt $f$. Bakteriologie. Ref. Bd. IXI.

Bürger, Zeitschrift f. Immunitätsforschung. Bd. XXIr.

Eg is u. Kolli, Berl. Klin. Wochenschrift. Nr. 23 u. Centralblatt f. Bakteriologie. 1914. Ref. Bd. I,XI.

Eichholz, Münchener med. Wochenschrift. 1913.

Friedberger u. Mita, Deutsche med. Wochenschrift. 1912.

Galambos, Zeitschrift f. Immunitätsforschung. 1913. Bd. XIX.

Gaffky u. Heubner, Veröffentl. a.d.Geb.d. Aledd.Verv. Bd. II.

Jochmann, Med. Klinik. 1913.

Joseph, Deutsche med. Wochenschrift. 1914. Nr. 11.

Kammann, Biochemische Zeitschrift., 1914. Bd, LIX.

Kolle a. Hetsch, 1911. 3. Auf.

Neufeld u. Händel, Berliner klin. Wochenschrift. 1912.

Mongour, Compt. rend. Soc. de Biologie. 1912. T. LXXII.

Moss, Journ. of Amer. med. Assoc. 1910. Vol. LV.

Schulz, Berliner klin. Wochenschrift. Nr. 8 u. 9.

A. Bankier Sloan, Med. Klinik. Ref, 1911.

Weil, Centralblatt f. Balcteriologie. Ref. Bd. LX.

Wolf-Eisner, Ebenda. Ref. Bd. J,V. 